\title{
Toward a Theory of Micro-kindness: Developing Positive Actions in Multicultural Education
}

\author{
Judson Laughter \\ University of Tennessee
}

U. S. A.

ABSTRACT: This conceptual article seeks to build on empirical research on microaggressions by introducing a corollary strand of inquiry: microkindnesses. A definition and examples of microaggressions are synthesized from a review of psychological and educational research; a particular limitation of this research is then discussed. A definition of micro-kindness is offered and supported by a list of actions to provide multicultural educators examples of micro-kindness in practice, which might inspire inclusion of micro-kindness in course curricula or as a subject of inquiry.

\author{
A First Meeting \\ Microaggressions \\ Micro-kindness \\ Toward the Practice of Micro-kindness \\ A Second Meeting \\ References
}

How can we choose love when we have experienced so little of it? We choose love by taking small steps of love every time there is an opportunity. A smile, a handshake, a word of encouragement, a phone call, a card, an embrace, a kind greeting, a gesture of support, a moment of attention, a helping hand, a present, a financial contribution, a visit-all these are little steps toward love.

Each step is like a candle burning in the night. It does not take the darkness away, but it guides us through the darkness. When we look back after many small steps of love, we will discover that we have made a long and beautiful journey.

(Nouwen, 1997, 15 June)

\section{A First Meeting}

I first met Anton (pseudonym) in May of 2013, not knowing that he would offer me the opportunity to take one of the small steps Nouwen describes. The 
spring semester had just ended and my days were a mix of faculty meetings, student appointments, and periods of trying to catch up on what I had neglected throughout April. As such, I found myself walking to a trolley stop around noon, where stood a young Black man dressed in jeans and a t-shirt. I made eye contact and nodded, as I would with any other pedestrian, and then returned to reading the newspaper. Anton was the first to speak:

"Are you waiting for the trolley?"

"I am."

"They changed the route because of the festivals and stuff this summer."

"Really? I saw that the road was blocked where I normally get on so I came down here."

"Yeah, they reroute up there but they still pick up here."

"Cool."

"Hey, man. Thank you for talking to me."

With that last line began a conversation about Anton's day and the multiple interactions he had experienced as he moved around Knoxville, Tennessee, on foot and public transit between home and work.

The list of his experiences included classic examples of microaggressions, the "brief and commonplace verbal, behavioral, and environmental indignities, whether intentional or unintentional, that communicate hostile, derogatory, or negative racial slights and insults" (Sue, Capodilupo, Torino, Bucceri, Holder, Nadal, \& Esquilin, 2007, p. 273): People crossed the street or sped up when they saw him coming. People locked their car doors when he passed. People assumed he was about to ask them for money and quickly mumbled excuses without him saying a word. It was my response to this last example that, I believe, broke through the ice completely:

"That's crazy. It's the crazy old White guys who ask you for money downtown, not the young Black men."

With that response, Anton first stared in disbelief before smiling, offering his hand for a handshake, and saying, "Thank you for saying that."

\section{Microaggressions}

The purpose of this conceptual article is to build on the current foundation of empirical research in both psychology and education on microaggressions, a term coined first by Pierce (1970), and to introduce a corollary strand that will interest multicultural educators who can read plenty about negative consequences but who want to read about possible positive actions. To that end, I begin with a brief synthesis of the research on microaggressions and describe how multicultural educators might find it useful. 
Most research on microaggressions describes what a microaggression constitutes and how a target might react. Notably, there is a consistent return to the impact of the cumulative burden (Pierce, 1995) posed by repeated exposure. It is not that any one interaction leads to measureable outcomes but the accumulation of low-level attacks over time that can take a mental, physical, social, and spiritual toll. In short, research on microaggressions does not necessarily consider the impact of a single, large-scale event but instead looks at the impact of repeated, pervasive interactions. In education, microaggressions have been associated with lower college completion rates (Minikel-Lacocque, 2013), decreased feelings of daily well-being (Ong et al., 2013), increased feelings of stress (Torres-Harding, 2012), and the exclusion of scholars of color from educational research (Solórzano, 1998).

While still a rare subject of inquiry (Minikel-Lacocque, 2013), most research on microaggressions emerges from the fields of mental health and psychology and thus focuses on the experiences of individuals. However, several educational researchers (e.g., Minikel-Lacocque, 2013; Solórzano \& Yosso, 2000; Yosso, Smith, Ceja, \& Solórzano, 2009) have found conceptions of microaggressions an important reality with which multicultural educators must wrestle; as such, the topic has begun to receive some recent attention.

For example, an educator might find it useful to differentiate among microassaults, microinsults, and microinvalidations because each of these represent potential occurrences in the classroom; a taxonomy laying out the differences (Sue, Capodilupo, Torino, Bucceri, Holder, Nadal, \& Esquilin, 2007) would be useful for a teacher trying to react to a racial slur as opposed to someone commenting, "Oh, that's not racism; that's just someone being naïve." For a teacher wanting some idea of the impact of microaggressions on students, Torres-Harding, Andrade, and Romero Diaz (2012) have introduced the Racial Microaggressions Scale (RMAS); such a scale could provide useful data to a teacher and spark some interesting classroom discussion.

While such research often focuses on Black/White racial dynamics (Solórzano, Ceja, \& Yosso, 2000; Sue, Nadal, Capodilupo, Lin, Rivera, \&Torino, 2008), there are now studies exploring microaggressions and Asian Americans (Ong, Burrow, Fuller-Rowell, Ja, \& Sue, 2013), "Latin@ students" (MinikelLacocque, 2013), and international students in the United States (Kim \& Kim, 2010). There has also been inquiry into reactions to microaggressions between same-race peers (Solórzano et al., 2000; Yosso, 2006) and into group reactions (Yosso, Smith, Ceja, \& Solórzano, 2009).

Likewise, the work on racial microaggressions has been used as a foundation for studies of microaggressions vis-à-vis gender (Pierce, 1995; Solórzano, 1998; Sue, 2010; Capodilupo, Nadal, Corman, Hamit, Lyons, \& Weinberg, 2010), sexual and transgender orientation (Nadal, Rivera, \& Corpus, 2010), ability (Keller \& Galgay, 2010), class (Smith \& Redington, 2010), and religion (Nadal, Issa, Griffin, Hamit, \& Lyons, 2010). 
In each case, the (seemingly subconscious) actions of an empowered aggressor diminish in some way the feelings of humanity and value within a target. A multicultural educator might find it useful to draw on inquiry into microaggressions with participants more representative of a classroom's demographics.

While much of the educational research focuses on higher education, the implications drawn from the impact of interpersonal microaggressions, racial jokes, and institutional microaggressions (Yosso et al., 2009) could be readily and effectively adapted into any schooling context; it might be included in professional development and teacher preparation. Likewise, multicultural educators at every level might find research on microaggressions an important framework for helping to define the impact of -isms in their own contexts. Such research would better inform a teacher about the impact of a racial joke or a use of the n-word in a middle school classroom, the impact of stereotype threat (Steele \& Aronson, 1995) on standardized tests in high school, or the impact of assurances of colorblindness (Sleeter, 2001) in the preparation of teachers for diverse classrooms.

However, the research tends to focus only on the manifestation of microaggressions: How do targets feel after an attack? How do they react? How do they successfully contest such attacks and perhaps engage the attacker? How do they become part of a broader solution in a school or university? Minikel-Lacocque (2013) recently described the "Catch-22-type dilemma" experienced by the targets of microaggressions, calling for more research on "contested microaggressions" and exploration of these experiences from both targets' and aggressors' points of view (p. 460).

This focus places an unfair burden on the targets of microaggressions, expecting them to be the only ones to do something:

What is lacking is research that points to adaptive ways of handing microaggressions by people of color and suggestions of how to increase the awareness and sensitivity of Whites to microaggressions so that they accept responsibility for their behaviors and for changing them. (Sue et al., 2007, p. 279)

While reactive work is important and necessary, we must also focus proactively on the actions of those responsible. To that end, I propose a corollary area for consideration: micro-kindnesses.

\section{Micro-kindnesses}

In proposing this shift, I rely on anecdotal evidence and my own reanalysis of the extant empirical research: that is, there is not yet any empirical research moving toward a theory or exploring the effects of micro-kindnesses. Likewise, this focus is not included in the extant research on microaggressions, although at least one call has been made for such, and that just recently: 
Whereas these studies focused on NA [negative affect] and microaggressions, future studies should be broadened conceptually to include assessments of PA [positive affect] and positive events. (Ong et al., 2013, p. 196)

This reveals a fundamental limitation to research on microaggressions: we are only asking questions about negative consequences. While multicultural educators need to know what is going wrong, they should also have ideas and suggestions for positive actions they might take.

There are hints at micro-kindnesses in the extant research. For example, Minikel-Lacocque (2013) reported on Antonio's interactions in his college dorm and how most of the White students "stick to themselves" (p. 449). Implications are drawn from interviews with Antonio to describe how microaggressions might contribute to his negative perceptions of White students. However, there is the indication that Antonio's "circle of friends does include some White students" ( $p$. 449). While not the focus on this study, we are left to wonder if Antonio had any positive interactions with these friends. To what ends? Did any positive interactions help drive his perceptions of "what 'White guys' are like" (p. 449)?

Likewise, Sue et al. (2007) described a microaggression that occurred between an author and a flight attendant. After Sue (a self-identified Asian American) and an (author-identified) African American colleague were asked to move to the back of a plane because the flight attendant "needed to distribute weight on the plane evenly" (p. 275), Sue and his colleague were left to wonder if their race were a driving factor in this interaction. The "resentment, irritation, and anger" (p. 275) experienced by Sue and his colleague led to a later discussion with the flight attendant sparked by Sue's question, "Did you know that you asked two passengers of color to step to the rear of the bus?" (p. 275). According to Sue, this discussion resulted only in the attendant refusing to continue talking to him, with the caveat "For every allegation I made, she seemed to have a rational reason for her actions" (p. 275). Was there an opportunity for deeper interpersonal dialogue missed here? While the attendant's actions certainly may have been either consciously or subconsciously motivated by racism, a microaggression's tendency toward invisibility was broken. Could that dissonance have been turned toward something healthier rather than leaving Sue with "a sour taste in [his] mouth" (p. 275)?

Addressing these questions might not even require new data collection, just new research questions and data analysis protocols. Minikel-Lacocque (2013) used in-depth interviews. Ong et al. (2013) analyzed diaries. Solórzano (1998) examined open-ended surveys and interviews. Sue et al. (2007) collected numerous personal narratives of counselors. Yosso et al. (2009) conducted a series of focus groups. Perhaps examples of micro-kindnesses already exist in these rich data sources and need a different focus to emerge. Obviously, only the original researchers have access to these data, and their original research questions did not focus on the potential for positive interactions. Thus, follow-up interviews and member checking toward those ends might be necessary, but there might not be a need to start from scratch. 
Much of the research on racial microaggressions is posited on the idea that recent decades have seen shifts in racism with moves from conscious to subconscious, explicit to implied (Solórzano, 1998; Sue et al., 2007). In short, Jim Crow allowed conscious and active expressions of racism that would be readily scorned and condemned today even as the same underlying racism remains. Likewise, multicultural educators and their students may hold strong anti-racist beliefs but fail to act in accordance with those beliefs or in ways that take into account the perceptions and feelings of the target.

Specific and intentional inquiry into micro-kindnesses in interpersonal and inter-demographic interactions would accomplish two things: (1) it would bring our racist, classist, sexist systems of thought out of the subconscious and into focus for aggressors and (2) it would provide models of action that specifically fight the cumulative impact of microaggressions as experienced by the target.

While most of the research on microaggressions has emerged from the fields of mental health and psychology (Minikel-Lacocque, 2013), those fields have shown some movement in this direction. For example, Zautra, Affleck, Tennen, Reich, and Davis (2005) included positive and negative affects in their study of psychological well-being, complicating assumptions about well-being as a bipolar, unidimensional construct. Perhaps their model might be adapted to specifically examine the impact of interpersonal interactions in a classroom or school.

Likewise, in building on this research, the work of multicultural educators would find support for the desire to do something that works toward upending our racist, classist, and sexist systems of schooling. Instead of being relegated only to recognizing what not to do, the inclusion and discussion of micro-kindnesses would provide the opposite: a description of conscious actions to pursue both in the classroom and in the wider community.

To the end of promoting the inclusion of micro-kindnesses in such research and education, I define micro-kindnesses as follows: brief verbal, behavioral, or environmental acts of respect, consciously intended to provide a potential space for positive and humanizing interaction.

\section{Toward the Practice of Micro-Kindnesses}

To pursue increasing awareness and sensitivity toward microaggressions, I present a list of 20 potential micro-kindnesses, homage to the now seminal list of McIntosh's invisible knapsack of White privilege (1989). This list provides potential examples of micro-kindness in practice to inspire considerations of micro-kindness as a focus in multicultural education. Trying to engage such a list could be problematic for several reasons, three of which I address here: 
This list might be understood as a checklist. This list is not a checklist for ending microaggressions; it is a description of a personal posture toward other human beings that might move us toward ending microaggressions by making our subconscious tendencies available to critique and recognizing the subjectivity of the other. For example, multicultural educators and students often want to turn action into belief but are left asking, "Yes, but how do we do it?" (Ladson-Billings, 2006). Instead of trying to provide a checklist to cover every context (which would be impossible), this list describes a posture:

[Student teachers] began to see multicultural education and teaching for social justice as less a thing and more an ethical position they need to take in order to ensure that students are getting the education to which they are entitled. (p. 40)

To encourage such use, I have included with each item a brief description of the posture intended to be engendered or reflected.

This list cannot predict every response. This list has been generated from my own experiences, as exemplified by my interaction with Anton described above, and from discussions with friends and colleagues claiming diverse demographic identities. These conversations have been invaluable in helping me see how actions will be interpreted in many ways. For example, the third recommendation about crossing the street may promote anxiety, particularly after a year in which the United States has seen the killings of several unarmed Black youths.

In posing this list, I refer to the participant of micro-kindnesses to complement the vocabulary of target used in the research cited above. Participant is meant to recognize the personhood and dignity of both parties. However, this list only goes as far as to communicate the potential for positive interaction between participants. The definition of micro-kindness proposed above begins with "brief verbal, behavioral, or environmental acts" but does not end there. The impact of micro-kindness emerges from the potential such acts have for opening a space for "positive and humanizing interaction."

This list is intended for teachers and students. The potential for positive impact through micro-kindness extends to all of society and should not be confined just to a school or classroom. However, the foundation of this article is educational research into microaggressions and its potential for impacting multicultural education. As such, I have split the list between Micro-kindness in the Classroom and Micro-kindness in the Community. This distinction is artificial, and any action could be adapted to different contexts by focusing on the posture and not the specific action. In addition, each item is not just an action for an individual but a potential foundation for explicit classroom discussion around both the action and the intended posture. 
For example, the first item lists an action that a teacher or student might take in a school setting. However, any member of a community might take this action as a potential for opening positive interaction. Likewise, a teacher could build on this action through classroom discussion and activity where teacher and student alike use it as a foundation for developing positive and humanizing interactions in and out of school.

\section{Micro-kindness in the Classroom}

1. Smile and acknowledge a participant when walking down the street, the hall, or across an open space like a cafeteria or playground.

2. Do not cross the hall or other space if you see a participant approaching from the opposite direction, even if that means going out of your own way. This communicates recognition of another traveler and a willingness to share personal space, if only briefly.

3. Cross the hall or other space to pass closer to a participant travelling in the opposite direction, even if that means going out of your way. (Doing this when you are both travelling in the same direction might be thought of as threatening, so use discretion.) This provides the potential for a positive interaction (see \# 1).

4. Choose to sit closer to a participant in the cafeteria or auditorium, even if another seat is available. (Again, be aware of how this might be interpreted negatively.) This communicates to another human being that you are comfortable with their presence.

5. Refuse to use binary pronouns like "he" or "she." This promotes the reality that a demographic category is not a binary and reduces the chances for oppression, because "oppression itself relies on binaries" (Hackman, 2010, p. 317).

6. Understand that there is no such thing as Standard English or a neutral accent. This reduces the chance for linguistic racism, which may be one of the most pervasive forms of racism across multiple demographic categories (Delpit \& Dowdy, 2002).

7. Seek out curricular materials and develop lessons that focus on participants. This demonstrates to every student that they have a place in the academy and that people like them have made contributions to scholastic knowledge.

8. Seek out curricular materials and develop lessons that engage students' funds of knowledge (González, Moll, \& Amanti, 2005). This also demonstrates to every student that they have a place in the academy and that there are multiple knowledges that all deserve a place in schools. 
9. Use demographic labels when discussing empowered groups, not just marginalized groups; that is, refer to yourself as White, male, or cis. This helps dispel the notion that you are somehow the norm.

10. Instead of asking a participant "What do [insert group] think about that?" ask "What do you think about that?" This addresses the participant as a human being with individual and unique opinions and attacks the fallacy of heteronormativity.

\section{Micro-kindness in the Community}

1. While it is safe practice to lock car doors when driving, do so immediately when starting the car and not when driving by a participant. This prevents you from inadvertently communicating that you fear a participant's presence.

2. Choose activities or organizations that lead you to be with participants as colleagues, not just as community service. This offers you the opportunity to have genuine, positive interactions.

3. Take time to engage in conversation with a participant while waiting on line. This provides the potential for a positive interaction.

4. Assume a participant is a manager or person-in-charge and interact with respect. This communicates that you do not traffic in sociocultural notions of who is allowed to be in charge.

5. Choose a checkout line run by a participant and use the chance to engage in conversation, even if it means waiting in a longer line. This provides the potential for a positive interaction.

6. Ask to be seated in less desirable seats at a restaurant or theater if you notice participants have been seated there. This points out to the participants and to the establishment that you are not willing to participate in discriminatory seating.

7. Instead of asking a participant, "Where are you from?" ask, "Are you from [insert local area]?" This lessens feelings of being excluded and communicates that anyone can be local.

8. React with disbelief when people describe themselves as demographically colorblind. This disseminates the reality that such colorblindness might ignore the cultural reality of a participant.

9. Do not allow inflammatory language or posts on social media to go unchallenged. Realistically, you cannot counter every negative thing posted on a social media site, but do realize that you have a broad audience through these platforms. 
10. Recognize that your culture is only one of many and is neither natural to nor the norm for everyone.

I cannot predict the potential impact of these actions or the effect they might achieve if wider spread and bolstered by curricular adoption and explicit use in the classroom. Neither do I naïvely assume that enough people practicing microkindness will be the answer to all our inter- and intra-demographic issues. However, the practice, study, and teaching of micro-kindness can only help support the work of broader systemic change for social justice. As Nouwen tells us, one candle does not take away the darkness, but each one helps.

\section{A Second Meeting}

Two weeks after I met Anton, I boarded a trolley headed home, listening to a podcast and generally unaware of my surroundings after a day in front of a computer screen. Immediately after I sat down, I felt a tap on my shoulder. I removed my headphones as I turned to see Anton smiling and offering his hand:

"Hey man, it's Anton. We talked like two weeks ago, remember?"

With that, Anton began to recount how, during the last two weeks, his outlook on life and people had been so much more positive after our first meeting. He told me how he realized that just knowing one other person got it was important and that he was able to overlook a lot of other people. That was the word he used: "overlook." I asked him if that was a good thing or a bad thing, thinking that "overlooking" people could go either way:

"Oh, it's a good thing. A good thing. I mean, they can do or say what they want but that don't bother me. I'm able to overlook their negativity and just tell them, 'you have a blessed day."

I have not seen Anton again, but I look for him now during my commute or when I am out and about downtown. Perhaps a single micro-kindness can counteract numerous microaggressions, just as one candle can dispel much darkness.

\section{References}

Capodilupo, C. M., Nadal, K. L., Corman, L., Hamit, S., Lyons, O. B., \& Weinberg, A. (2010). The manifestation of gender microaggressions. In D. W. Sue (Ed.), Microaggressions and marginality: Manifestation, dynamics, and impact (pp. 193-216). Hoboken, NJ: John Wiley \& Sons.

Delpit, L., \& Dowdy, J. K. (Eds.). (2002). The skin that we speak: Thoughts on language and culture in the classroom. New York, NY: The New Press. 
González, N., Moll, L. C., \& Amanti, C. (Eds.). (2005). Funds of knowledge: Theorizing practices in households, communities, and classrooms. New York, NY: Routledge.

Hackman, H. (2010). Sexism. In M. Adams, W. J. Blumenfeld, C. Castañeda, H. W. Hackman, M. L. Peters, \& X. Zúñiga (Eds.), Readings for diversity and social justice (2nd ed.)(pp. 315-320). New York, NY: Routledge.

Keller, R. M., \& Galgay, C. E. (2010). Microaggressive experiences of people with disabilities. In D. W. Sue (Ed.), Microaggressions and marginality: Manifestation, dynamics, and impact (pp. 241-268). Hoboken, NJ: John Wiley \& Sons.

Kim, S., \& Kim, R. H. (2010). Microaggressions experienced by international students attending U.S. institutions of higher education. In D. W. Sue (Ed.), Microaggressions and marginality: Manifestation, dynamics, and impact (pp. 171-192). Hoboken, NJ: John Wiley \& Sons.

Ladson-Billings, G. (2006). "Yes, but how do we do it?" Practicing culturally relevant pedagogy. In J. Landsman \& C. W. Lewis (Eds.), White teachers/diverse classrooms: A guide to building inclusive schools, promoting high expectations, and eliminating racism (pp. 29-42). Sterling, VA: Stylus.

Mclntosh, P. (1989, July/August). White privilege: Unpacking the invisible knapsack. Peace and Freedom, 10-12.

Minikel-Lacocque, J. (2013). Racism, college, and the power of words: Racial microaggressions reconsidered. American Educational Research Journal, 50(3), 432-465.

Nadal, K. L., Issa, M. A., Griffin, K. E., Hamit, S., \& Lyons, O. B. (2010). Religious microaggressions in the United States: Mental health implications for religious minority groups. In D. W. Sue (Ed.), Microaggressions and marginality: Manifestation, dynamics, and impact (pp. 287-312). Hoboken, $\mathrm{NJ}$ : John Wiley \& Sons.

Nadal, K. L., Rivera, D. P., \& Corpus, M. J. H. (2010). Sexual orientation and transgender microaggressions. In D. W. Sue (Ed.), Microaggressions and marginality: Manifestation, dynamics, and impact (pp. 217-240). Hoboken, NJ: John Wiley \& Sons.

Nouwen, H. J. M. (1997). Bread for the journey: A daybook of wisdom and faith. New York, NY: Harper Collins.

Ong, A. D., Burrow, A. L., Fuller-Rowell, T. E., Ja, N. M., \& Sue, D. W. (2013). Racial microaggressions and daily well-being among Asian Americans. Journal of Counseling Psychology, 60(2), 188-199.

Pierce, C. (1970). Offensive mechanisms. In F. Barbour (Ed.), The Black seventies (pp. 265-282). Boston, MA: Porter Sargent. 
Pierce, C. (1995). Stress analogs of racism and sexism: Terrorism, torture, and disaster. In C. Willie, P. Reiker, B. Kramer, \& B. Brown (Eds.), Mental health, racism, and sexism (pp. 277-293). Pittsburgh, PA: University of Pittsburgh Press.

Smith, L., \& Redington, R. M. (2010). Class dismissed: Making the case for the study of classist microaggressions. In D. W. Sue (Ed.), Microaggressions and marginality: Manifestation, dynamics, and impact (pp. 269-286). Hoboken, NJ: John Wiley \& Sons.

Solórzano, D. G. (1998). Critical race theory, race and gender microaggressions, and the experience of Chicana and Chicano scholars. International Journal of Qualitative Studies in Education, 11(1), 121-136.

Solórzano, D. G., Ceja, M., \& Yosso, T. (2000). Critical race theory, racial microaggressions, and campus racial climate: The experiences of African American college students. Journal of Negro Education, 69(1/2), 60-73.

Sleeter, C. E. (2001). Preparing teachers for culturally diverse schools: Research and the overwhelming presence of Whiteness. Journal of Teacher Education, 52(2), 94-106.

Steele, C. M., \& Aronson, J. (1995). Stereotype threat and the intellectual test performance of African Americans. Journal of Personality and Social Psychology, 69(5), 797-811.

Sue, D. W. (2010). Microaggressions in everyday life: Race, gender, and sexual orientation. Hoboken, NJ: John Wiley \& Sons.

Sue, D. W., Capodilupo, C. M., Torino, G. C., Bucceri, J. M., Holder, A. M. B., Nadal, K. L., \& Esquilin, M. (2007). Racial microaggressions in everyday life: Implications for clinical practice. American Psychologist, 62(4), 271286.

Sue, D. W., Nadal, K. L., Capodilupo, C. M., Lin, A. I., Rivera, D. P., \& Torino, G. C. (2008). Racial microaggressions against Black Americans: Implications for counseling. Journal of Counseling and Development, 86(3), 330-338.

Torres-Harding, S. R., Andrade, A. L., \& Romero Diaz, C. E. (2012). The racial microaggressions scale (RMAS): A new scale to measure experiences of racial microaggressions in people of color. Cultural Diversity and Ethnic Minority Psychology, 18(2), 153-164.

Yosso, T. J. (2006). Critical race counterstories along the Chicana/Chicano educational pipeline. New York, NY: Routledge.

Yosso, T. J., Smith, W. A., Ceja, M., \& Solórzano, D. G. (2009). Critical race theory, racial microaggressions, and campus racial climate for Latino/a undergraduates. Harvard Educational Review, 79(4), 659-690. 
Zautra, A. J., Affleck, G. G., Tennen, H., Reich, J. W., \& Davis, M. C. (2005). Dynamic approaches to emotions and stress in everyday life: Bolger and Zuckerman reloaded with positive as well as negative affects. Journal of Personality, 73(6), 1511-1538. 